\title{
The EU Administration of Mostar: Implications for the EU's evolving peacebuilding approach
}

\author{
ANNIKA BJÖRKDAHL \\ Lund University \\ annika.björkdahl@svet.lu.se
}

\begin{abstract}
This article explores the EU's efforts to reunify and reconstruct Mostar through the seminal experiment of EUAM (1994-1996), which combined peacebuilding with urban reconstruction in an innovative way. The aim is to identify lessons to be learned from the experiences of EUAM that can assist the EU to adjust its peacebuilding approach to better address post-conflict divides in cities where the EU currently is engaged. Cities divided by violent conflict tend to freeze the conflict, as they remained divided regardless of a conflict settlement, and they become serious obstacles to peace and a challenge to peacebuilding. Far too little is known about the role of urban space in building peace in ethno-nationally contested cities. By marrying critical urban studies with critical peacebuilding literature this article brings novelty to EU-studies and advances our understanding of the EU's role in peacebuilding as well as in the Western Balkans.
\end{abstract}

Key words: European Union, divided city, Mostar, peacebuilding, reconstruction, urban.

\section{Introduction}

The EU is emerging as a major player in regional and global peacebuilding. However, its evolving peacebuilding approach and praxis contain contradictions and complexities as well as aspirations and potential. The Western Balkans well illustrates this, as it has long been the testing ground for the EU's new approaches to peace and security. It is for example in the Western Balkans that the EU developed its regional approach to peacebuilding and it is also where the EU undertook the seminal experiment to administrate a city - the contested city of Mostar in BosniaHerzegovina. This article explores the EU's reconstruction, reintegration and reunification efforts in the divided city of Mostar and their implication for the EU's evolving peacebuilding approach.

The Bosnian city of Mostar emerged from the Bosnian war as a divided city with unresolved ethno-nationalistic conflicts. It became a platform for expressing conflicting sovereignty claims. The ethno-national conflict was spatialized and turned into material and symbolic spatial relations as Croatian and Bosniac communities split the city into two autonomous halves along the Austro-Hungarian Boulevard in 1993. ${ }^{1}$ Although the symbolic Stari Most (the Old Bridge) has been rebuilt, the two

\footnotetext{
${ }^{1}$ S. Bollens, Urban Peacebuilding in divided societies, Belfast and Johannesburg, Boulder, Westview Press,
} 
communities remain deeply divided and the city is still contested more than 15 years after the signing of the Dayton Peace Accord that brought an end to the war in Bosnia-Herzegovina.

This divide in Mostar is a spatial, social and political construct that is closely linked with identities. Such division in a city is rarely a mutually accepted status quo and control of the city space continues to be contested. Cities divided by violent conflict tend to freeze the conflict, as they remained divided regardless of an official conflict settlement. They become symbols of the continuities rather than discontinuities between war and peace. ${ }^{2}$ From a peacebuilding perspective, the divided city is both an obstacle to peace and an indication of failed peacebuilding. 3 The contested and ethno-nationally divided city of Mostar is a case in point.

By marrying critical urban studies with critical peacebuilding literature, this article brings novelty to EU-studies and advances our understanding of the EU's evolving peacebuilding approach and praxis. 4 Intrigued by the unique experience of EUAM, this article asks what lessons the EU can draw from the efforts to reintegrate and reunify the Bosnian city of Mostar that are of relevance to other cities partitioned by violent conflict, and investigates the potential implications of EUAM for the EU's evolving peacebuilding approach. Surprisingly, little scholarly attention has been paid to the extraordinary measure adopted by the EU to administrate, rebuild and reintegrate Mostar. 5 In addition, the evolving EU peacebuilding framework as yet seems not to have included any lessons learned from this experiment of administrating a post-conflict divided city. Although EUAM has been evaluated by the EC Court of Auditors and the European Parliament, the innovation of peacebuilding rescaled to the city level has not been properly assessed, and the original ideas and practice derived from EUAM have not been mainstreamed into the EU's evolving peacebuilding framework. ${ }^{6}$ The EU's long-term engagement in the partitioned city of Belfast through the EU Peace Fund I and II, for example, fail to demonstrate that the EU peacebuilding approach has incorporated lessons from

\footnotetext{
1999.

${ }^{2}$ S. Bollens, Cities, nationalism and democratization. London, Routledge, 2007; H. Al-Harithy, Lessons in Post-War Reconstruction. Case study from Lebanon in the Aftermath of the 2006 War, London \& New York, Routledge, 2010; J. Calame \& E.R. Charlesworth, Divided cities: Belfast, Beirut, Jerusalem, Mostar, and Nicosia, Philadelphia, University of Pennsylvania Press, 2009.

3 It refers to dynamic processes that aim to balance the twin aims of consolidating peace and averting relapse into conflict by identifying, alleviating and eliminating underlying causes of conflict (B. Boutros-Ghali, $A n$ Agenda for Peace: Preventive diplomacy, peacemaking and peacekeeping. UN Dept. of Public Information, Yearbook of the United Nations, 1992; J. Lederach, Building Peace. Sustainable Reconciliation in Divided Societies. Washington, United States Institute of Peace, 1997; J. Lederach, The Moral Imagination: The Art And Soul of Building Peace, Oxford, Oxford University Press, 2005).

4 D. Davies and N. Libertun de Duran (eds.), Cities \& sovereignty: identity politics in urban spaces, Bloomington, Ind., Indiana University Press, 2011; J. Davies and D. L. Imbroscio (eds.), Critical urban studies: new directions, Albany, N.Y., State University of New York Press, 2009; E. Newman et al., New Perspectives on Liberal Peacebuilding, Tokyo, UN University Press, 2009; O. Richmond, Critical Advances in Peacebuilding, Basingstoke, Palgrave Macmillan, 2010; O. Richmond, A Post-Liberal Peace: The Infrapolitics of Peacebuilding, New York, London, Routledge, 2011.

5 For exceptions see F. Bieber, 'Local institutional engineering: A tale of two cities, Mostar and Brcko,' International Peacekeeping, Vol. 12, No. 3, 2005, pp. 420-433; L. Vetters, 'The Power of Administrative Categories: Emerging Notions of Citizenship in the Divided City of Mostar,' Ethnopolitics, Vol. 6, No. 2, 2007, pp. 187-209; C. Stahn, The Law and Practice of Internaitonal Territorial Administration, Cambridge, Cambridge University Press, 2008. pp. 301-308.

${ }^{6}$ Special Report No. 2/96 concerning the accounts of the Administrator and the European Union Administration, Mostar (EUAM) accompanied by the replies of the Commission and the Administrator of Mostar, European Parliament Report on Special Report No 2/96 para. 18.
} 
EUAM and is able to take into account the urban dynamics.7 Neither does the EU's approach to peacebuilding in Cyprus employ innovative ideas to overcome the ethnicized divisions of urban space in Nicosia, suggesting that the EU has been able to adjust its peacebuilding approach to the urban level. ${ }^{8}$ Hence, this article focuses on this novel combination of peacebuilding and urban planning comprised in EUAM's ambitions for Mostar. By doing so, this article aims to demonstrate that lessons can be learned from EUAM that can assist the EU to adjust its peacebuilding approach to better address divides in post-conflict cities such as Nicosia and Belfast where the EU is currently engaged.

The article unfolds in four parts. First, the evolving EU peacebuilding approach is discussed. Second, the divisions in the city of Mostar are mapped out and investigated. Third, the efforts by EUAM are assessed in the context of the EU's evolving peacebuilding approach. Based on the evaluation of EUAM, the article concludes with a critical discussion of the complexities, contradictions and potentials of EU peacebuilding, arguing that EU can move beyond the state-centrism that plagues its peacebuilding approach by learning from the experience of EUAM and rescaling its peacebuilding efforts to the urban level. Rescaling peacebuilding to focus on the city is assisted by the EU principle of subsidiarity, and it may contribute to facilitate the EU buzzwords of 'local ownership of peace processes,' 'participatory peacebuilding,' 'stakeholder engagement,' etc. into its peacebuilding praxis.

\section{Contradictions and aspirations in the EU peacebuilding approach}

The EU's emerging peacebuilding approach is driven by the EU's different practices and accumulated experiences on ground. It is not yet a coherent approach as it contains contradictions, developments, and learning by doing.

\section{The underlying philosphy of the EU's approach to peacebuilding}

The EU in itself is conceived as a peace project, and its post-war experience of integration based on integrationalist and functionalist thinking about peace is the foundation for its emerging peacebuilding approach. Consequently, what the EU is rather than what the EU does seems important to its achievements as a peacebuilder. The strong self-image of the EU is articulated in the "discourse of universal ethics which defines the EU as a 'power for good' and a 'peacebuilder" on the international scene. 9 A number of core values that guide the internal relations among its member

\footnotetext{
7 See assessments of the EU Peace Fund I \& II for Northern Ireland which supports grass root initiatives to address the legacy of the Troubles but fails to demonstrate the adaption of peacebuilding to the urban dynamics in Byrne et al. 'Building Trust and Goodwill in Northern Ireland and the Border Counties: The impact of Economic Aid on the Peace Process,' Irish Political Studies, Vol. 24, No. 3, 2009, pp. 337-363, Byrne et al., 'Economic Assistance, Development and Peacebuilding: The Role of the IFI and EU Peace II Fund in Northern Ireland,' Civil Wars, Vol. 10, No. 2, 2008, pp. 106-124, C. Lynch, 'Evaluating the Peace-Building Impact of Structural Funds Programmes: The EU Programme for Peace and Reconciliation in Northern Ireland,' Evaluation, Vol. 13, No. 1, 2007, pp. 8-31.

${ }^{8}$ O. Richmond, 'Shared Sovereignty and the Politics of Peace: Evaluating the EU's catalytic framework in the Mediterranean,' International Affairs, Vol. 82, No. 1, 2001, pp. 149-176. The Bi-Communal initiative, The Nicosia Master Plan, to change the image of the city has gained the attention and financial support of the EU. F. Gaffikin, M. Mceldowney \& K. Sterrett, 'Creating Shared Public Space in the Contested City: The Role of Urban Design,' Journal of Urban Design, Vol. 15, No. 4, 2010, pp.493-513.

9 L. Aggestam, 'Introduction: Ethical power Europe?', International Affairs, Vol. 84, No. 1, 2008, pp. 1-11; A. Björkdahl, 'Building Peace- Normative and Military Power in EU Peace operations', in R. Whitman (ed.), Normative Power Europe: Empirical and Theoretical Perspectives, Basingstoke, Palgrave MacMillan, 2011.
} 
state have emerged within the EU, such as sustainable peace, consensual democracy, human rights, the rule of law, inclusive equality, social solidarity, sustainable development and good governance. ${ }^{10}$

These core values are also guiding the development of its peacebuilding approach and praxis. Its overall goals for peacebuilding are to prevent violent conflict and build sustainable peace through development aid, the promotion of democracy, the rule of law, human rights, and through strengthening civil society and facilitating the construction of the liberal state, or where applicable, Member State. ${ }^{11}$ In practice, EU peacebuilding has been made up of disparate activities by disparate bodies. For example, ESDP missions have been responsible for security, policing and the promotion of the rule of law; the Commission has engaged in democratization, welfare and human rights promotion. The diplomatic role of the high representative and various EU special representatives have been framed in the context of the CFSP, apart from the broad role of EU institutions in creating transitional administrations, and the role played by the EU as a donor. With the Lisbon treaty and the European External Action Service (EEAS), new challenges and opportunities are provided for the EU in the field of peacebuilding.

The EU's main theatres of engagement have been where conflict issues are pressing, and where other international peacebuilding actors, such as the UN, have called for assistance and in areas where members have interests, most significantly in the EU region and connected regions..$^{12}$ The potential of the EU's transformative influence is evident in the Western Balkans, where the dynamics of peacebuilding are connected to the enlargement process emphasised by the attraction of membership. ${ }^{13}$

\section{The Western Balkans - a testing ground for EU peacebuilding practices}

The evolution of the EU peacebuilding approach and practice reveals both innovations and challenges. ${ }^{14}$ The Western Balkans have been the testing ground for the development of the EU's approach to peace and security and the EU's experience in this domain has contributed to the development of the EU peacebuilding framework. ${ }^{15}$

The wars in former Yugoslavia were, in the eyes of many Europeans, a symbol of collective failure. Yet, it was against the backdrop of the Balkan conflicts in the 1990's that the EU began to frame its role in peace and security. New strategies, tools and

\footnotetext{
${ }^{10}$ I. Manners, 'The normative ethics of the European Union,' International Affairs, Vol. 84, No. 1, 2008, pp. 4560.

${ }^{11}$ I do not argue that the EU peacebuilding approach as yet represents a coherent approach that is systematically translated into practice. However, I offer a critical analysis of how it is gradually emerging through various practices.

12 J. Zielonka, (ed.) Paradoxes of European Foreign Policy, The Hague, Kluwer Law International, 1998.

${ }^{13}$ A. Björkdahl, 'Europeisering eller Balkanisering? EU som statsbyggare på västra Balkan,' in Magnus Jerneck ed. Fred i Realpolitikens skugga, Lund, Studentlitteratur, 2009; M. Abramovitz, et al., 'The Western Balkans and the EU: The Hour of Europe,' Challiot papers, June, 2011; G. Knaus \& F. Martin, 'Travails of the European Raj,' Journal of Democracy, Vol. 14, No. 3, 2003, pp. 60-74; H. Grabbe, The EU's Transformative Power: Europeanization through Conditionality in Central and Eastern Europe, New York, Palgrave Macmillan, 2006.

14 O. Richmond et al., 'The Emerging EU Peacebuilding Framework: Confirming or Transcending Liberal Peacebuilding,' Cambridge Review of International Affairs, Vol.24, No. 3, 2011, pp. 449-469.

15 R. Belloni, 'The Western Balkans and European Integration: Lessons, Prospects, and Obstacles,' Journal of Balkan and Near Eastern Studies, Vol. 11, No. 3, 2009, pp. 313-331. A. Björkdahl, 'Building Peace- Normative and Military Power in EU Peace operations,' op. cit.; M. Abramovitz, et al., op. cit.
} 
capacities were been tried out and fine-tuned in the Western Balkans. In 2003, the EU tested its conflict prevention idea and launched the CONCORDIA conflict prevention mission in the Former Yugoslav Republic of Macedonia. The EU played, and still plays, a major role in the post-conflict situation in Bosnia. It deployed its first police operation (EUPM) 2003, and its first military operation EUFOR Althea in Bosnia. The growth of different schemes has been a defining feature of the Balkan political landscape since the Dayton Peace Accords. The EU also developed a more comprehensive regional approach after this conflict, initiated by the EU Council Conclusions of 26-27 February 1996.16 This regional approach subsequently took shape through the 'Process of stability and good-neighbourly relations in SouthEastern Europe.' From the initial steps of the Royamount Process, the Stabilisation and Association Process (SAP) of the late 1990s was to support regional cooperation and to start harmonize the societies and the laws in the Western Balkans with the EU's acquis communitare. ${ }^{17}$ The Western Balkans have also seen EU engagement through the Community Assistance for Reconstruction, Development and Stabilisation (CARDS) launched in 2001, and as the integrationist logic holds, the countries in the Western Balkans have successively signed the Instrument of PreAccession Assistance. The EU funding schemes are based on the assumption that the Western Balkans will become "European" in terms of gradually adopting EU values and standards and that the states will eventually be the image of EU MemberStates. ${ }^{18}$

\section{The potentials and paradoxes of EU peacebuilding}

The regional approach that was developed in the Western Balkans married elements of the Common Security and Defence Policy (CSDP) and the enlargement processes and this regional approach has emerged as a cornerstone of EU peacebuilding in the Western Balkans. This approach is linked to the European Union's own experience of regional integration and a firm belief in regional integration and interdependencies as a key to durable peace. ${ }^{19}$ In the words of the European Parliament, "regional cooperation is one of the consistent elements of European integration itself [and] serves to bring about peaceful cooperation, economic development and democratisation and has therefore repeatedly been advanced and promoted by the EU as a successful example and development model for other regions of the world."2o With this approach, the EU established a coordinated set of political and economic conditionalities aimed at infrastructure, reconstruction and institution-building. ${ }^{21}$ In the Western Balkans, conditionality mainly led to fake compliance, partial compliance or non-compliance provoking imposed compliance. ${ }^{22}$ In response to the experience of Balkan post-conflict politics and the general complexities of post-

\footnotetext{
${ }^{16}$ D. Becheve, 'Carrots, sticks and norms: the EU and regional cooperation in Southeast Europe,' Journal of Southern Europe and the Balkans, Vol. 8, No. 1, 2006, pp. 27-43.

${ }^{17} \mathrm{~K}$. Coles, 'Ambivalent Builders: Europeanization the production of Difference and International in BosniaHerzegovina,' in X. Bougarel, et al. (eds.), The New Bosnian Mosaic: Identities, Memories and Moral Claims in Post-War Society, Burlington, Ashgate, 2007.

${ }_{18}$ D. Chandler, Bosnia: Faking Democracy after Dayton, $2^{\text {nd }}$ ed. London, Pluto Press, 20oo; A. Juncos, 'The EU's post-Conflict Intervention in Bosnia and Herzegovina: (re)Integrating the Balkans and/or (re)Inventing the EU?,'Southeast European Politics, Vol. VI, No. 2, 2005, pp. 88-108.

19 N. Nicolaidis and R. Howse, 'This is my EUtopia”: narrative as power,' Journal of Common Market Studies, 40(4), 2002, pp. 767-792.

20 European Council 1997.

${ }^{21}$ T. Freyburg \& S. Richter, 'National identity matters: the limited impact of EU political conditionality in the Western Balkans,' Journal of European Public Policy, Vol. 17, No. 2, 2010, pp. 263-281.

${ }^{22}$ G. Noutcheva, 'Fake, partial and imposed compliance: the limits of the EU's normative power in the Western Balkans,' Journal of European Public Policy, Vol. 16, No. 7, 2009, pp. 1065-1084.
} 
conflict societies, the EU promoted civil society from the grassroots to counterbalance elite power, enhance accountability of the elite by the society, and to circumvent political stagnation. ${ }^{23}$ Hence promoting civil society has emerged as the second cornerstone of its peacebuilding approach. Yet, it rests on a liberal notion of civil society as "relatively free from ethno-nationalism and generally oriented towards the norms and values of the peacebuilding and statebuilding project." 24 This was obviously not the case in the Western Balkans, in particular in Bosnia-Herzegovina.

It is a paradox that the EU - itself a post-modern polity, transcending territorial sovereignty and challenging traditional notions of national sovereignty - develops an approach to peacebuilding that remains to a large extent state-centric. For example, when engaging with the post-conflict societies, the EU does so through the state, and it prefers governments or powerful elites as interlocutors on the state level. ${ }^{25}$ This state centrism obviously challenges, and to some extent contradicts, the two other cornerstones of the EU peacebuilding framework - the regionalist approach and the civil society approach. Hence, there are some obvious contradictions inherent in the EU peacbuilding approach and expressed in its praxis.

Despite its obvious contradictions, the evolving peacebuilding approach of the EU may provide novel opportunities if lessons could be learnt from EUAM's experimental 'Mostar model' of urban reconstruction. EUAM was indeed "an experiment of international governance at the urban level, operating under the internationalized structure of the Dayton Agreement." 26 It was also a unique effort to combine post-conflict peacebuilding with urban planning to reconstruct a city divided by violent conflict. Far too little is known about the role of urban space in building peace in ethno-nationally contested cities. It is evident that the political meanings of urban space and diversities of power relations, as embodied in urban space, have implications for how to build a sustainable peace. The prospects for urban peacebuilding in terms of space- and place-making have implications for the evolving EU peacebuilding approach.

\section{The Contested City of Mostar}

Situated on both shores of the Neretva River, Mostar ${ }^{27}$ was widely held to be one of the most multi-ethnic cities in the former Yugoslavia. It was characterized by mixed residential areas, apart from the Old Town Mostar where mainly Bosniacs resided, and about one-third of marriages were ethnically mixed. ${ }^{28}$ As a consequence of war and peacebuilding attempts, Mostar emerged as a partitioned city resistant to efforts at peacebuilding and reconstruction.

\section{Creating facts on the ground}

\footnotetext{
${ }^{23}$ R. Belloni, 'Civil Society and Peacebuilding in Bosnia-Herzegovina,' Journal of Peace Research, Vol. 38, No. 2, 2001, pp. 163-180.

24 S. Kappler \& O. Richmond, 'Peacebuilding and culture in Bosnia and Herzegovina: Resistance or Emancipation?,' Security Dialogue, Vol. 42, No. 3, 2011, pp. 261-278.

25 S. Kappler \& O. Richmond, op. cit. pp. 265-268.

${ }^{26}$ C. Stahn op. cit. p. 301.

${ }_{27}$ Mostar is less populated than Sarajevo and the city's pre-war population was about 126.0oo according to the 1991 census (S.A. Bollens, Cities, nationalism and democratization, op. cit.).

${ }^{28}$ S. Bollens, Cities, nationalism and democratization, op. cit. p. 184.
} 
During the break up of Yugoslavia, ${ }^{29}$ Mostar was the battlefront in the "war within the war" between Bosnian-Croats and Bosniacs, effectively dividing the city in a western Bosnian-Croat part and an eastern Bosniac part. $3^{\circ}$ Mostar became the site of some of the most serious violence and destruction in the region, to the extent that the devastation of Mostar has been characterised as an Urbicid. ${ }^{31}$ Historic monuments, cultural property and religious buildings were deliberately targeted during the war to destroy the memory of the mixed city. Bridges, for example, had a particular cultural meaning in Mostar - apart from their obvious economic and military significance. Nine were dynamited by the JNA in the spring of 1992.32 The famous old bridge 'Stari Most' survived the first war, but was brought down by Croat tanks shelling it in the second war (November 1993). At that point no bridge remained.33

After initially jointly defending the city against the Bosnian-Serb forces, alliances shifted and fighting broke out between HVO (Croatian Defense Council) and the Army of $\mathrm{BiH}$ in the spring of 1993. It was a close-fought war street by street, building by building, leading to a complete division of the urban community. 34 Two separate war-time administrations were set up to manage the urban space under their control, and crossing to the other side of the city was formally restrained and only a limited number of people were allowed to pass. 35

The demographic balance of Mostar shifted drastically in course of the war. The total city population dropped sharply despite a large influx of displaced persons from surrounding areas into both sides of the city, altering the composition of the city's population. ${ }^{36}$ In the direct aftermath of the war, the communal division was severe and few dared to cross the border, which ran throughout the city. The end of the war did not mean an end to the ethnic cleansing, which continued in a quieter version years after the Dayton Accords brought peace to $\mathrm{BiH}$ and members of other ethnic groups either left voluntarily or were forcibly expelled.37 Resettling of refugees and internally displaced persons as frontier populations was another attempt to use urban space to foster confrontation. ${ }^{38}$

The territorial division of the city continued and was cemented in the post-war era.

\footnotetext{
29 F. Wilmer, The Social Construction of Man, the State and War. Identity, Conflict and Violence in the Former Yugoslavia, New York \& London, Routledge, 2002; D. Zarkov, The Body of War. media, ethnicity, and gender in the break-up of Yugoslavia, Duke University Press, 2007; B. Blitz (ed.), War and Change in the Balkans, Cambridge, Cambridge University Press, 2006; R. Lukic \& A. Lynch, Europe from the Balkans to the Urals. The Disintegration of Yugoslavia and the Soviet Union,Oxford, Oxford University Press, 1996; S. Woodward, Balkan Tragedy, Washington DC, The Brookings Institute, 1995.

30 S. Woodward, op. cit., pp. 18, 279.

${ }^{31}$ Kresimir cited in J. Yarwood, Rebuilding Mostar: Reconstruction in a War Zone. TRP (Town Planning Review) Special Studies, No. 3. Liverpool, Liverpool University Press, 1999.

${ }^{2}$ C. Grodach, 'Reconstituting identity and history in post-war Mostar, Bosnia-Herzegovina,' City, Vol. 6, No. 2, 2002, pp. 61-82.

33 Yarwood, op. cit., p. 7.

34 F. Bieber, op. cit.; S.A. Bollens, Cities, nationalism and democratization, op. cit., p. 185-188.

35 F. Bieber, op. cit., Vetters op. cit.

${ }^{36}$ The number of Serbs decreased to less than five percent and the Serb community is today marginal in Mostar. In the absence of a power-war census, it is estimated that Croats make up the largest group of about 50-60 percent of Mostars approximately 100.000 residents, outnumbering Bosniaks composing about 40 per cent, but who before the war had been more numerous (International Crisis Group, 'Bosnia: A Test of Political Maturity in Mostar,' Europe Briefing, No. 54, 27 July, Sarajevo, Brussels, 2009.

37 Bieber, op. cit.

${ }^{38}$ W. Pullan, 'Frontier Urbanism: the periphery at the centre of contested cities,' The Journal of Architecture, Vol. 18, No. 1, 2011, pp. 15-35.
} 
The public, collective sphere that had existed prior to the war became fragmented, subordinated and manipulated and the collective interests of the city collapsed and dissolved. The divide in the city was the result of a politics of confrontation and negotiation in the war and the post-war period. This "ethnization" of urban space production constructed an ethno-nationally fractured cityspace. 39

\section{The spatial expression of ethno-national politics}

Mostar had geopolitical, symbolic value as well as geostrategic importance. As Mostar emerged from the ethno-national conflict, the production of urban space was inevitably linked to the power relations at the end of the war, territoriality and the ambitions to control land, expressions of identity, and to distribution of economic benefits and costs.

Mostar's contested nature made it a target of the post-war nationalist leaderships keen to consolidate their grip of the city symbolically and demographically. As a consequence, it became a platform for political projects through which different, and often clashing, visions of the city and of peace were imagined and expressed. ${ }^{40}$ The real conflict over Mostar was about the city's role in the broader Croat community, the Croats' position in $\mathrm{BiH}$ and, more generally, how majority rule and minority rights should co-exist. Mostar was viewed as the capital of the Bosnian-Croat secessionist project and it was the political base of the Bosnian Croats' leadership. Through Mostar the Bosnian-Croats tried to compensate for the fact that the Dayton Peace Accords did not provide them with a home territorial unite. Despite a formal power-sharing system to govern Mostar, similar to the one at the national level, an illegal parallel structure of Croat-controlled Herzeg Bosna - a para-state was set up. ${ }^{41}$

It is within the city that ethnic identities are formed through urban memories and everyday experiences, and in Mostar this was an on-going struggle in the post-war period. $4^{2}$ The contestations involved in the reconstruction of the symbolic urban space were linked to processes of identity formation, cultural reinterpretations, and political reconfigurations. Mostar was the site for the Bosnian-Croats ambitions to preserve their national culture, and the city became notorious for the gigantic cross on Mount Hum above the city. The Old bridge of Mostar (Stari Most) also has importance in reconstituting the Mostar identity in the post-war years, but not as often envisioned by international donors as a symbol to connect the two communities on each side of the river. In fact Stari Most connected the Bosniac community on the eastern riverbank with its foothold on the western bank. This $16^{\text {th }}$ century Ottoman bridge became a symbol in the process of reinterpreting Bosnia's legacy of Ottoman city space. 43 Focusing on the politics of space and place - the struggles and political relations concerning the material and symbolic aspects of particular communities helped to crystallize the notion of belonging and how it was formed in practice. 44

\footnotetext{
39 Cityspace refers to the constantly eolvolving, intentionally planned, and politically charged spatialization of social life.

$4^{\circ}$ International Crisis Group, Reunifying Mostar: Opportunities for Progress. ICG Report no. 90, 19 April, 2000.

${ }^{41}$ International Crisis Group, 'Reunifying Mostar, Opportunities for progress,' Balkan Report, No. 90, Sarajevo, Washington, Brussels, 2000; R. Belloni \& S. Deane 'From Belfast to Bosnia: Piecemeal Peacemaking and the Role of Institutional Learning,' Civil Wars, Vol. 7, No. 3, 2005, pp. 219-243.

$4^{2}$ R. Kallus \& Z. Kolodney, 'Politics of Urban Space in an Ethno-Nationally Contested City: Negotiating

(Co)Existence in Wadi Nisnas,' Journal of Urban Design, Vol. 15, No. 3, 2010, pp. 403- 424, p. 406.

43 Grodach, op.cit.

44 Kallus \& Kolodney, op. cit., p. 406.
} 
The urban space of Mostar comprised territorial and non-territorial divisions, layers of conflicted meanings, as well as urban forms and the spatial practices, and endemic to them were important aspects of power but also resistance towards power. 45 Postwar urban governance and urbanism became means by which Mostar's war profiteers solidify their hold on power and reinforce ethno-nationalist divisions. It is strongly evident that the formation of boundaries was linked to ethno-national identity and power relations. The right to the city became a key issue and the divisions reflected the winner-loser relations in governance structures as well as in realities on the ground. 46

\section{EUAM and the reconstruction of Mostar}

Despite the often-cited 'fiasco' of the EU's involvement during the violent dissolution of Yugoslavia, the EU's various interventions in the region served to foster the EU's approach to peacebuilding. The EU's administration of Mostar was an extraordinary example of direct international management of a city and a highly unusual strategy of urban reconstruction. 47 Through the Washington Agreement of March 1994, Mostar became an "area under EU administration," but remained officially part of the Federation of BiH. ${ }^{8}$ The EUAM's efforts to reintegrate and reunify Mostar were about peace-making, but also about space- and place-making.

\section{Peace-making}

Peace-making included attempts at negotiations, mediations, and to accommodate and balance the competing interests of the different communities residing within Mostar. More than thirty major agreements 49 between the two sides were negotiated where representatives of the international community repeatedly brokered deals on the same issues: return of refugees and displaced persons, unification of police, unification of city and canton budgets, unification of city and canton institutions. Eventually the negotiations resulted in the Washington Agreement signed in 1994, which established a Federation of Bosniacs and Bosnian-Croats. As part of this agreement, Mostar was recognised as a joint Bosniac-Croat city and the capital of the mixed Croat-Bosniac Herzegovina-Neretva canton. Following the Washington Agreement, top officials from the two sides met in Geneva to decide the future of Mostar. As the Croat side was opposed to an UN administration in Mostar a Memorandum of Understanding (MOU) was signed in Geneva on 5 of July 1994 between the Bosnian-Croats and the Bosniacs (exluding the Bosnian-Serbs) and this political compromise placed Mostar under EU administration (EUAM) for an interim period between July 1994-July 1996. This was later included as an annex to the

\footnotetext{
45 c.f. D. Hayden, The Power of Place: Urban Landscapes as Public History, Cambridge, MIT Press, $1995 ; \mathrm{K}$. Dovey,'Memory, democracy and urban space: Bankok's path to democracy,' Journal of Urban Design, Vol. 6, No. 3, 2001, pp. 265-282.

${ }^{46}$ Kallus \& Kolodney, op. cit., p. 406.

47 Yarwood, op. cit.

48 The EU Administration of Mostar was established by Council Decisions 94/308/CFSP, OJEC [1994] L 134/1 and 94/790/CFSP OJ $1994 \mathrm{~L} 326 / 2$, repeatedly extended and terminated by Decisions 96/442/CFSP, OJEC [1996] L 185/1, 96/476/CFSP, OJEC [1996] L 195/1, 96/508/CFSP, OJEC [1996] L 212/1 and 96/744/CFSP, OJEC [1996] L 340/1.

49 The Washington Agreement, Dayton Peace Accord, the Interim Statue and the Rome Agreement are the most important ones all addressing how Mostar was to be reconstituted.
} 
comprehensive Dayton Peace Accords (DPA).50 The city was to be demilitarised and EUAM was tasked with establishing a multi-ethnic, unified city administration.

Initially, EUAM accepted three different entities: EUAM and the two established municipalities, the Bosnian-Croat and the Bosniac. Recognizing that reunifying Mostar was more than rebuilding the city - it was a political peacebuilding project efforts were made to overcome segregation and partition, though these proved to be futile. Holding local democratic elections for a single city council was part of this, as were efforts to negotiate to acceptance a single city statue. ${ }^{1}$ The EUAM envisaged that the city administration would be created once the elections were held and the legal statue was adopted. Yet, the negotiations to create a single unified city council led to protracted negotiations in 1995 .

The opposition against EUAM came initially from the Bosnian-Serbs/Serbs who continued to shell the city, including Hotel Ero the seat of EUAM, during the EUAM mandate. This seriously hampered EUAM's efforts at reconstruction. Over time, the main opposition was found among the Bosnian-Croats and the Croat Democratic Union (HDZ). Riots and attacks against Hans Koschnik, the first EU administrator, by supporters of HDZ were an unsubtle attempt to intimidate the EU administrator and a response to a decree by Koschnik to increase the size of the shared central zone, beyond what the Bosnian-Croat leadership had agreed to (see below). $5^{2}$ The BosnianCroat mayor of west Mostar rejected the plan and suspended his cooperation with EUAM. The violent resistance led to a summit meeting which included representatives from all the parties to the Dayton accords. As a result, an additional Croatian Muslim agreement was reached which led the EU to give in to some of the demands and reduce the size of the shared central zone more in line with the initial proposal agreed to by the Bosnian-Croats.53 This compromise arrangement led the mayor of the Bosniac West part of Mostar to resign in protest.54

\section{Space-making}

Space-making in peacebuilding relates peace to space as peace remains abstract and ungrounded until spatialized through a process of materialization and contextualization. 55 In Mostar, space-making can be regarded as peacebuilding efforts to neutralize or counter the ethnification of urban space by the parties to the conflict and the spatialization of power-relations.

The EU alone invested about 200 million euros to reconstruct Mostar with the intent to constructively undo the city's wartime partition, ethnic cleavages and ethnonational political power structures. ${ }^{6}$ In a rather short period of time, EUAM reconstruction efforts transformed and reconfigured Mostar from a pre-war mixed municipality that encompassed all the urban area into a politically fragmented urban area containing six ethnically homogenous municipalities (three Croat and three Bosniac) confirming the wartime divisions, and one city administration with its

\footnotetext{
$5^{\circ}$ Bieber, op. cit.

${ }^{51}$ Yarwood, op. cit.

52 M. Klemencic and C. Schofield, op. cit., p. 74.

53 Yarwood, op. cit.

54 M. Klemencic and C. Schofield, op. cit., p. 75.

55 E. Soya, Postmetropolis: Critical Studies of Cities and Regions, Oxford, Blackwell, 2000, pp. 9-10.

${ }^{6}$ S. Bollens, Cities, nationalism and democratization, op. cit., p. 189.
} 
central zone jurisdiction comprising the historic town centre.57 The peacebuilding efforts to reintegrate the city came to concentrate on the "central zone," and focussed on creating a shared, de-politicized public space.

In early 1994, the only shared public space was hotel Ero, the seat of EUAM, situated on the confrontation line. All people, without exception were guaranteed access to the hotel. As such, hotel Ero became a beacon of hope to ordinary people. $5^{8}$ It was also at the hotel where the EU Administrator Mr. Koschnick helped to instigate talks between both sides, for example on a single unified city council and the boundaries of the central zone. A series of meetings were held to get both sides to agree to the boundaries of the central zone. The initial Bosnian-Croat proposal for the internal division of the city was essentially to respect the de facto line of separation and create three municipalities on each side. In contrast, the Bosniacs favoured a totally united city, which, because of the large number of displaced Bosniacs in East Mostar, would give their community an overall majority in the city. ${ }^{59}$ The Bosnian-Croats wanted a very small zone if any at all, as they did not want to surrender its war gains and the Bosniacs naturally wanted a very big zone. ${ }^{60}$ In the EUAM proposal, the central zone was to include all joint public facilities such as the post office, railway station, bus station, joint police headquarters, grammar school, public utility office, Hotel Ero and the four Federal Ministries required by the DPA to be placed in Mostar. Surprisingly, the Bosnian-Croats agreed to the proposal under pressure from Zagreb, but the Bosniacs rejected it. As the EU Administrator arbitrated, he issued a decree, which defined a much larger central zone incorporating a housing area penetrating far into Bosnian-Croat territory. Satisfying the Bosniac politicians, it outraged the Bosnian-Croat leader who immediately called for demonstrations against the EUAM at hotel Ero.

At the time EUAM was set up the city was littered with street barricades, consisting of heavy lorries piled with sandbags, steel sheets and rubbish. The largest was a Bosnian-Croat barricade placed right outside Hotel Ero itself. Refusing to remove their barricade when asked, the EUAM asked UNPROFOR (United Nations Protection Force) to do so, and the Bosnian-Croats were forced to accept the fait accompli. Soon after, all the other material barriers came down. ${ }^{61}$

Most local people saw the task of EUAM only in terms of reconstructing the wardamaged city and repairing material objects, specifically bridges, buildings and infrastructure, while tasks such as education, culture, public finance and institutional development were undervalued.62 EUAM took pride in rebuilding five of the ten bridges across the Neretva River. Rebuilding the city meant restoring everyday life and this inspired gratitude among the inhabitants. This was an incentive for local political leaders to collaborate as they might gain advantages from cooperation and receive some of the gratitude and its inevitable political benefits. Hence, reconstruction projects became increasingly linked to the political aspects of peacebuilding and to the implementation of the Dayton Peace Accords.

\footnotetext{
57 Bieber, op. cit.

$5^{8}$ Yarwood, op. cit., p. 13.

59 M. Klemencic and C. Schofield, 'Mostar: Make or Break for the Federation,' IBRU Boundary and Security Bulletin, Summer 1996.

${ }^{60}$ Yarwood, op. cit., p. 30; J. Demichelis, NGO's and Peacebuilding in Bosnia's Ethnically Divided Cities, Special Report, 32, Washington DC, United Institute of Peace, 1998.

61 Yarwood, op. cit., p. 4.

62 J. Demichelis, 'NGO’s and Peacebuilding in Bosnia's Ethnically Divided Cities,' op. cit.
} 


\section{Place-making}

The governing principles that shaped the EUAM mission were derived from the EU framework of governance, which is shaped by key principles such as subsidiarity ${ }^{6} 3$ and accountability as well as mechanisms of consultations. In the post-war reconstruction and peacebuilding of Mostar, these EU principles were intended to ensure local participation, partnership between EUAM and local stakeholders as well as to enhance the sense of local ownership in the reconstruction of the city.

The MOU granted the EU administrator "the powers necessary to fulfil the aims and principles of the EU Administration....and to administer the Mostar city municipality properly and efficiently including regulatory powers and final decision-making authority in the executive field." 64 Yet, the EU administrator's powers were constrained in the sense that they were exercised within the framework of the Federation of BiH and by the terms of the MOU. EUAM was to comply with domestic laws and the decision-making authority was embedded in the institutional structure of the municipality. This meant, among other things, that EUAM was to exercise its authority in cooperation with the local council and operate in consultation and collaboration with local parties according to the principle of subsidiarity. In cases where domestic institutions were better placed and capable to make decisions, EUAM was to defer to local decision-making institutions. The EU administrator appointed an Advisory Council representing prominent local politicians to allow different communities to have a voice in the reconstruction and reunification processes. Two mayors of Mostar were the 'Principal Counsellors.' Meetings were held every month and it was believed that these meetings did contribute to reconcile the former warring parties. As the different departments of EUAM were set up, each departmental director would be supplied by a EU Member State and they were to have two codirectors, nominated by the Bosnian-Croat and the Bosniac sides. ${ }^{65}$

In the context of peacebuilding and reconstruction in Mostar, subsidiarity was married with urban planning in a novel way to produce shared public spaces that promote people's safety and sense of belonging. The principle of subsidiarity, which is an organizing principle that dictates that matters ought to be handled at the lowest or least centralized level of competent authority, strengthened the urban planning idea of place-making. This bottom-up approach to urban reconstruction capitalizes on community assets, inspiration and potential. The overarching philosophy of the reconstruction department was that EUAM was to assist the Mostarians in rebuilding their city, not to try to expropriate that process. In terms of reconstruction, the principle of subsidiarity was put into practice and consultation with local communities and recruitment of local professionals became the standard operating procedures for the reconstruction department. Although working in an ad hoc manner, a unified Urban Planning Team was established that produced an AllMostar Structure Plan. There was a proposal from the head of the EUAM Reconstruction Department to integrate the Reconstruction Department into a local

${ }^{63}$ Subsidiarity is perhaps the best known general principle of European Union Law. According to this principle, the EU may only act (i.e. make laws) where the actions of individual countries are insufficient. The principle was established in the 1992 Treaty of Maastricht, but at the local level it was already a key element of the European Charter of Local Self-Government, and instrument of the Council of Europé promulgated in 1985, which states that public responsibilities should be decentralized.

64 Cited in C. Stahn, op. cit., pp. 303-304.

65 Yarwood, op. cit., p. 12. 
administration for urban planning and development until the end of the mandate to avoid it having a superior or independent existence. The proposal was rejected by the head of EUAM, as there was a preference for a more top-down approach based on finding high-level political agreements to everyday issues of urban planning. This of course further intensified the politicisation of the reconstruction processes. 66

\section{Lessons learned from EUAM}

EUAM has a mixed record, but there are some important lessons to be learned both from the failures and the successes of the efforts at reconstruction and reintegration of Mostar.

First, the EU's reconstruction in Mostar was above all about space-making to undo the ethnification of urban space, to alter the territorial control of the communities and to counter the institutional and governance parallelism, which had created two cities in one. Yet, EUAM and the WEU police turned a blind eye to the continued expulsion of non-Bosnian-Croat citizens from West Mostar through terrorist attacks and violent ethnically motivated acts and through fear and hate including statements in the media. ${ }^{67}$ Consequently, Mostar was transformed by the war, and by the peacebuilding process from a pre-war mixed municipality to an ethno-nationally partitioned and segregated city. Mostar has remained divided despite a new city statue that imposed formal unification in the early $2004 .{ }^{68}$ This unfortunate outcome was mainly due to the inclusion of the terms of the initial MOU in the comprehensive Dayton Peace Accord, which, like many peace accords before it, relied on ethnic partition and decentralization to insure sustainability and stability, rather than integration and unification. This inevitably created tensions within the peacebuilding process aimed at reunification of Mostar, as the DPA contradicted the mandate of EUAM, which was to reintegrate the city. The negotiated interim city statute of 1996 recognised and thereby institutionalised the ethnic cleavages in the city. Thus Mostar became a highly decentralized city with far-reaching power-sharing system, echoing the consociationalist approach to power-sharing at the national level, but with the players reversed, i.e. the Bosniac majority at the entity level is replaced by a Croat majority in Mostar. In Mostar, urbanism and urban governance became means by which war profiteers solidified their power and reinforced divisions. Therefore instead of promoting urbanism, citywide interests became subordinate to specific political objectives. ${ }^{69}$ Public services including electricity, water supply, education and urban planning that should have been integrated citywide became politicized, and ethnicized and two parallel systems emerged. None of the city council's decisions to create common institutions and public companies were implemented. EUAM became increasingly reluctant to engage at the level of urban micro-scale and despite its early success there was a reticence to engage with urban planning. Hence, efforts to create a fairer and less territorial urban space largely failed. The EU's foreign aid and investment practices also exacerbated the parallelism and fuelled the development of two separate economies and two separate infrastructures in Mostar as EU aid targeted individual ethnically controlled municipalities rather than the central "unified" administration. In a critical assessment it is claimed that, "EU aid

\footnotetext{
66 Yarwood, op. cit., p. 23-25.

${ }^{67}$ International Crisis Group, 'Reunifying Mostar, Opportunities for progress,' Balkan Report, No. 90, Sarajevo, Washington, Brussels, 2000.

68 International Crisis Group, op. cit.; Bieber, op. cit.

69 S. Bollens, 'Urban Planning and Peacebuilding,' Progress in Planning, No. 66, 2006, pp. 67-139.
} 
reinforced ethnic apartheid." 70 Despite EUAM's success in reconstructing the wartime damage of the city's infrastructure, Mostar effectively demonstrates the limited long-term impact of EUAM efforts to counter the development of ethnonationalist "parallelism" and "re-unite" the ethnically divided city. ${ }^{71}$

Second, EUAM was concerned with peace-making and the negotiation of community identities and their spatial expressions, but was unable to manage the 'spoilers of the peace process.' The Croat Democratic Union (HDZ), for example, obstructed the more than thirty signed agreements (signed at the Federation and Canton level) and carried out a policy of maintaining a divided city and insisted on a Union of Croat Municipalities in Mostar. EUAM failed to see that the HDZ used negotiations as a tactic of political obstruction and protracted negotiations continued covering the same issues over and over again, while previous agreements were neither honoured nor implemented. As EUAM was largely unsuccessful in managing the spoilers and in combatting Croat defiance, Mostar became increasingly ungovernable. In a sense the EU did address symptoms of the ethno-nationally divided city in its removal of physical barriers along the dividing line, rebuilding the infrastructure and the building of symbolic bridges, and setting up a power-sharing structure of governance to prevent political domination by the ethnic majority political domination, but EUAM failed to address the underlying causes of the partition. In addition, EUAM's insistence on treating both sides equally, despite the obvious obstructionism on the part of the Croats, caused the EUAM to lose credibility.

Third, guided by the principle of subsidiarity EUAM was to reconstruct the city through a bottom up approach grounded in the local community and benefitting from local community assets, inspiration, and potential, to ultimately create shared urban spaces that promoted people's well being and safety. In Mostar place-making provided communities with an influence on the reconstruction processes, and the EUAM Reconstruction Department was open to local initiatives. This is mainly where the achievements of the EUAM are found. Through its unified reconstruction team and by working with local contractors selected through a tendering committee, EUAM was able to rebuild the infrastructure of the city, via the construction of schools, nurseries and basic public services, and re-establish freedom of movement within the city, which helped restore a sense of normal life in Mostar. However, it seems this bottom-up approach, combining urban planning and peacebuilding in an innovative way was not given full support at the top-level of EUAM.

\section{Conclusion: Implications for EUs peacebuilding praxis}

While post-war peacebuilding has been undertaken in cities ${ }^{72}$ as demonstrated by EUAM, peacebuilding strategies for cities where the city is recognized as a particular context and arena of such processes are rare. Administrating the divided city of Mostar was a visionary experiment by the EU. There were no precedents and no prior experience on which to draw. At the time, the EU was developing its approach to peacebuilding and conflict resolution and had very limited previous experience of

\footnotetext{
70 ICG 2000, p.6.

${ }^{71} \mathrm{~S}$. Bollens, Cities, nationalism and democratization, op. cit.; Bieber, op. cit.

72 J. Borneman, Belonging in the two Berlins, Cambridge, Cambridge University Press, 1992; P. Pickering, 'Generating social capital for bridging ethnic divisions in the Balkans: Case studies of two Bosniak cities,' Ethnic and Racial Studies, Vol. 29, No. 1, 2006, pp. 79-113; A. Sawalha, Reconstructing Beirut. Memory and Space in Postwar Arab city, Austin, University of Texas Press, 2010.
} 
engaging in peacebuilding. As the EU has gained more experience in the field and its approach to peacebuilding has evolved the lessons from administrating Mostar can be seen in a new light.

The division in Mostar persisted regardless of the Dayton Peace Accord, which was negotiated at the state level and successfully brought an end to the war in BosniaHerzegovina. This is an indication that the conventional focus of peacebuilding on the state-level may at times have counterproductive effects at sub-state levels. The DPA was not well suited for addressing the divisions of Mostar and in fact, the conflict in the city was frozen by the agreement. In some ways, the DPA also contradicted the mandate of EUAM as negotiated in the MOU. To overcome such obstacles to peacebuilding in divided cities, the EU approach needs to be able to rescale from state-centrism to the urban level in order to overcome frozen conflicts and cemented divides in contested cities and ultimately to produce a more localized, contextualized and thereby more legitimate peace. This of course challenges the conventional logic of peacebuilding as state building also to a large extent adhered to by the EU. Yet, by including the principle of subsidiarity in its peacebuilding approach, the EU would be better able to address ethnification of urban space and ensure local ownership.

The peacebuilding efforts in Mostar highlight the complexity, diversity, contestation and contradictions involved in the reconstruction of symbolic urban spaces after violent conflict. The limited success of EUAM indicates an inability to understand these complexities and contestations and to acknowledge the divided city as a major obstacle to building sustainable peace. The fact that EUAM reconstruction efforts cemented division and segregation of Mostar is an obvious indication of the failure of peacebuilding to manage the post-conflict urban context. This implies that the EU peacebuilding approach and praxis need to be able to capture the specificities of the urban as an arena for peacebuilding and that urban governance is a key means to address issues of ethnic co-existence, tolerance and democracy in the everyday. By paying attention to the urban and its dynamics, EU peacebuilding could uncover the workings of power relations and how these relations are reproduced in the cityspace.

As demonstrated by EUAM, peacebuilding strategies may fragment or integrate a city socially by either suppressing or dominating cultural identities or by reimagining identities in ways that nurture diversity within unity. Peacebuilding may reconstruct cities that either reinforce or seek to transcend community identities. 73 However, only by realizing the city's role as the spatial epicenter and battleground of violent conflict and accepting the city as a key arena of political participation can EU peacebuilding achieve its ambitions to overcome the visible and invisible divides in the city space.

Peace-making in contested and ethno-nationally divided cities is characterised by negotiations between various conflicting aspirations of different ethno-national groups and their powerful drive to establish ethnic control over the urban space to construct facts on the ground and thereby reality. 74 Negotiating the identity of urban communities in relation to the urban space is therefore an essential exercise for developing effective peacebuilding strategies to manage the conflicting aspirations and establishing legitimate governance structures at the urban level. By rescaling to the urban level it is possible to rethink the relationship between war, peace and

73 S. Bollens, Cities, nationalism and democratization, op. cit., p. 248.

74 S. Bollens, City and Soul in Divided Societies, Abingdon, Routledge, 2012. 
space. In adopting such an approach to peacebuilding that connects peace with space, the EU might be able to adjust peacebuilding to the cityspace. Such an approach should seek to connect the root causes of the conflict to the urban polarization in order to transform power asymmetries, attempt to decode space and to empower local peace constituencies and thereby contribute to reintegrating cities divided by violent conflict. 